\title{
A Literature Review on the Linear Elastic Material Properties Assigned in Finite Element Analyses in Dental Research
}

\author{
H. Kursat CELIK ${ }^{1 *}$, Simay KOC ${ }^{2}$, Alper KUSTARCI², Allan E.W. RENNIE ${ }^{3}$ \\ 1,* Dept. of Agr. Machinery and Technology Engineering, Akdeniz University, Antalya, Turkey \\ ${ }^{2}$ Dept. of Endodontics, Fac. of Dentistry, Akdeniz University, Antalya, Turkey \\ ${ }^{3}$ Engineering Dept., Lancaster University, Lancaster, United Kingdom
}

\author{
*Corresponding author : Dr H. Kursat CELIK \\ e mail : hkcelik@akdeniz.edu.tr \\ Tel : +902423106570 \\ Fax : :902423102479 \\ Address : Dept. of Agr.. Machinery and Technology Engineering, Akdeniz University, 07070, Antalya, Turkey
}

\begin{abstract}
Introduction: Finite element analysis (FEA) is a numerical procedure utilised in the engineering analysis of structures and is one of the most common numerical methods utilised in many research activities in dentistry such as implantology, prosthodontics and restoration. FEA can be considered a useful tool in order to describe the deformation aspects of dental components that cannot be measured easily by in vivo models. The geometry, material properties, finite element model (mesh structure) and boundary conditions defined for a particular FEA setup are the factors affecting the accuracy of the results of a FEA. Most especially, material models employed in FEA play a critical role, however, the literature cannot provide standard material models and data in agreement to be defined in the FEA studies handled specifically for human teeth. The aim of this study is reviewing the most utilised data related to material properties (limited to linear homogeneous isotropic material model) of the tooth components, evaluate the sources and reasons for the different values defined in dental research and provide filtered material data which can be utilised in related FEA studies.
\end{abstract}

Material and Methods: Electronic databases (PubMed and Web of Science) were reviewed for publications on FEA utilised in dentistry research. 155 research publications in total were considered in this paper. The search keywords of "finite element analysis", "finite element study", "mechanical properties" and "teeth" were combined through Boolean operators. The primary question under review was: "How were the material properties of the tooth components and numerical ranges, which are assigned in a FEA utilised in dental research, obtained and verified?".

Results: It was possible to determine sixteen different elastic modulus (EM) and seven Poisson' ratio (PR) values for enamel, eighteen EM and five PR values for dentin, sixteen EM and four PR values for periodontal ligament, eight EM and one PR values for pulp, ten EM and five PR values for cementum, twelve EM and four PR values for cortical bone, and eleven EM and four PR values for cancellous bone. As a result, it was seen that various EM, PR, density and strength values were considered and these were obtained from a limited number of FEA studies.

Conclusion: Average ranges for the core material properties such as EM, PR, density and strength values to be utilised in a FEA set up were presented. Further studies, specifically on determination of the mechanical properties of tooth components are still needed in order to successfully utilise them and confirm the accuracy of the FEA studies related to dental research.

KEYWORDS: Finite Element Analysis, Finite Element Study, Mechanical Properties, Tooth, Teeth, Dental.

\begin{tabular}{lll}
\hline${ }^{1, *}$ H. Kursat CELIK, PhD, Assoc. Prof. & hkcelik@akdeniz.edu.tr & ORCID: 0000-0001-8154-6993 \\
${ }^{2}$ Simay KOC, Dt., & simaykoc@akdeniz.edu.tr & ORCID: 0000-0002-9446-5655 \\
${ }^{2}$ Alper KUSTARCI, PhD, Prof. & akustarci@akdeniz.edu.tr & ORCID: 0000-0002-4942-3739 \\
${ }^{3}$ Allan E.W. RENNIE, PhD, Prof. & a.rennie@lancaster.ac.uk & ORCID:0000-0003-4568-316X
\end{tabular}

Word Counts : Approx. 3944 (Except references)

Number of Figures $\quad: 2$

Number of Tables $\quad: 2$ 


\section{INTRODUCTION}

Due to the complex biomechanical system of the oral cavity and its limited accessibility, most of the research of this type has been evaluated through in vitro models. Mostly, fracture resistance, deflection magnitude under respective load and mechanical properties of human tooth structures have been physically studied through destructive or non-destructive test methods in order to describe the deformation behaviour of the tooth components. In a structural context, it is commonly known that, if the stress magnitude under loading exceeds the elastic limit of the component's material, structural failure (plastic deformation) would initiate. However, physical and direct measurements of the structural stress distribution, determination of the location of the failure initialisation zones, threshold of the material strength and life of the components belonging to a complex oral system under loading would become a very difficult phenomenon to comprehend (1).

In the scope of computer aided engineering (CAE), finite element method-based analysis (FEM/FEA) is a numerical procedure that aims to describe/simulate the physical phenomena in a dimensional (1,2 or 3 dimensions) virtual environment through a mathematical approach. This provides a solution by generating a finite element discretisation which enables simulation of the behaviour of a materials deformation, from an elementary level to full component level, under pre-defined loading conditions (2). Related literature indicates that FEA was first utilised in the aerospace industry for solving structural, heat transfer and fluid flow based engineering problems in the 1960s and then spread to other research and engineering fields (2). The first use of this method in dentistry was published by Weinstein et al. in the field of implantology in 1979 (3). Since then, FEA has been frequently utilised in many research branches in dentistry such as prosthodontics, restorative dentistry and especially implantology in order to evaluate the deformation behaviour and to map structural stress distributions across teeth.

Although FEA may provide a good understanding of the physical phenomena of a situation, special care and scientific experience are needed during setup of the physical model in the digital environment in order to obtain accurate results and which is considered one of the most difficult aspects of the method $(4,5)$. In principle, four parameters affect the solution and accuracy of a FEA. These are the geometric feature of the object to be modelled, the element type and count (mesh structure), the material properties and the boundary conditions applied (6).

Since the method became popular in academia and industry, many software platforms, which promise FEM based solutions, are now commercially available. In fact, the fundamental application steps of the method consist of the same application algorithm steps for all such types of analysis. These steps are pre-processing, solution and post-processing stages. Pre-processing is the main setup procedure and consists of modelling, defining the material model and its properties, a description of the boundary conditions (loads and constraints) and creating the finite element model (mesh structure) (Figure 1).

(Figure 1. FEA application procedure)

The material properties assigned in a FEA is one of the primary calculation parameters in the pre-processing procedure. Specific to the dental research domain, based on experimental evidence related to real-life applications, the structure of teeth show similarities with human bone which exhibit viscoelastic behaviour under deformation phenomenon as the material behaviour of the teeth is also highly nonlinear and viscoelastic (7). This type of nonlinear viscoelastic behaviour 
can be considered as a time-dependent plasticity phenomenon, which is called viscoplasticity (8). It is also known that the structures of the tooth components are anisotropic and non-homogeneous (9). As such, a description of nonlinear viscoelastic behaviour of the teeth structure in a FEA would become a very complex phenomenon. Therefore, in order to explain the viscoelastic behaviour of the teeth, researchers are mostly forced to make simplifying assumptions and apply the theories of linear viscoelasticity or Hookean elasticity in dental FEA studies. Initial damage occurrence is considered in this type of simplification operation, as the damage occurrence in a solid structure can be easily determined by considering the critical stress point (mostly yield stress points) defined for the FEA model as the damage behaviour of teeth corresponding to the generation of microcracks over the yield stress point, like bones (10). However, any real material shows deviation from the ideal material models and numerical method-based simulation tools still have some limitations in modelling real-life responses in this manner. In this context, the scientific literature supports that in the static loading cases, homogeneous isotropic material model assumptions provide acceptable results when compared to an inhomogeneous anisotropic material model (11). These findings indicate that assigning isotropic homogenous linear elastic material model definitions for the tooth components utilised in the FEA studies would satisfactorily serve the major aim of a deformation analysis. This approach is commonly seen in dental research, however, appropriate assumptions should be made with respect to the material properties and the purpose of the simulation study in dental applications.

In describing an isotropic homogenous linear elastic material model in a FEA setup, the material properties of modulus of Elasticity (EM), Poisson's Ratio (PR) and material density have to be defined. Additionally, threshold deformation or critical stress magnitudes are given for damage evaluation, however, the difficulty is seen specifically for this point: there are a wide range of differences between the magnitudes of such specific material properties of EM, PR and the damage threshold points for the tooth components of enamel, dentin, periodontal ligament (PDL), pulp, cementum, cortical bone and cancellous bone (age factor has also been considered). In relation to medical applications, a detailed review on bone properties by Novitskaya et al. report a disagreement (changing values) on the material properties (most especially on EM) of human bone structures given in the literature (12-14). The components of a tooth would exhibit similar structural features with bone as a result of the nature of solid-like organic materials. It was also reported that different material testing methods (such as tensile, compression and bending tests) might provide different ranges for the material properties of bone structures (15). As such, the literature search related to FEA of tooth components was carefully conducted and the material properties and associated data utilised for the tooth components were carefully evaluated. Although some experimental studies did provide clear information related to material properties to be utilised in the numerical analysis, an agreement on specific material properties for tooth components could not be found (1). In addition, there was much replication reported in some publications for the selection of material properties which prove problematic in finding the main source of the data used. This was the main motivation for this paper. Consequently, it is acknowledged that although the application procedure for the FEA is the same, the data for the material properties of the same tooth components utilised in the dental FEA studies is highly variable. The literature has also indicated that a comprehensive and specific review work on material properties utilised in the FEA studies in dental research was limited.

The aim of this study is to review the most utilised data related to the material properties of teeth components and to evaluate the sources and reasons for the different values assigned in dental research and provide filtered material data which can be trusted when utilised in related FEA studies in the dental research area. 


\section{MATERIAL AND METHODS}

This literature review was conducted in accordance with the preferred reporting items for systematic reviews and metaanalyses (PRISMA) guidelines (Includes 155 suitable studies) (Figure 2). The research questions were described according to PICO (P: Population/Patient/Problem; I: Intervention; C: Comparison; O: Outcome) question: 'Related material properties of the tooth and numerical ranges, which are assigned in FEA studies in dentistry: how were they all obtained and what are the variances?' (in consideration of the isotropic homogenous linear elastic material model).

(Figure 2. The systematic flow chart of the study selection process)

\section{Literature Search Strategy}

An electronic search was limited to publications in the English language and performed in PubMed and Web of Science (WoS) databases using a series of search terms combined with the Boolean Operators "AND" and "OR", prior to $1^{\text {st }}$ December 2020. The keywords used in the electronic search were "finite element analysis", 'finite element study', 'mechanical properties' and 'teeth'. The following search string was developed with the combination of relevant keywords: (((finite element analysis) OR (finite element study)) AND (mechanical properties)) AND (teeth))). The core references of the material properties of teeth used in the studies obtained by an electronic search were also considered and these studies were also included in this review work.

\section{Inclusion and Exclusion Criteria}

Studies were included in this systematic review if they met the following inclusion criteria: (a) Finite element studies made in any field of dentistry such as implantology, prosthodontics, orthodontics and restorative dentistry related to the material properties of teeth; (b) The studies that include the value of EM and PR of at least two of the components of teeth (enamel, dentin, cementum, pulp, periodontal ligament, cortical, cancellous and/or compact bone); (c) Studies in other languages, studies that have no information about both EM and PR of the components of teeth and studies that include information about material properties of teeth but use different terminology were not included.

\section{Evaluation of Selected Studies}

Related to the publication search during the review, both titles and abstracts were carefully assessed. Full-text evaluation of the relevant articles was performed and the articles which were not considered eligible to the inclusion criteria were excluded from the study. Disagreements concerning the inclusion of a study were discussed by the authors until a decision was obtained by consensus. The following information was specified for each study and recorded on a data extraction form: EM, PR, density and the strength properties of the components of teeth (enamel, dentin, cementum, pulp, periodontal ligament and cortical cancellous and/or compact bone). A sample tooth model (mandibular left central incisor) and its component cross section is illustrated in Figure 3.

(Figure 3. A sample tooth model (mandibular left central incisor) and its component cross section) 


\section{RESULTS}

\section{Study Selection}

Using the present electronic search strategy, 871 records were collected from the PubMed and WoS databases. After removal of duplicates, 818 records remained for assessment of title and abstract and 316 of these studies were considered as eligible for full text analysis. 155 studies were considered as suitable for this review (Figure 2). The data of the related material properties of teeth obtained from the studies included are shown in detail in Table 1.

(Table 1. The data of the material properties of tooth components extracted from the studies included)

\section{Scoping Synthesis of Parameters}

There were sixteen different EM and seven PR values for enamel, eighteen EM and five PR values for dentin, sixteen EM and four PR values for periodontal ligament, eight EM and one PR values for pulp, ten EM and five PR values for cementum, twelve EM and four PR values for cortical bone, and eleven EM and four PR values for cancellous bone.

For enamel, the minimum value of EM was $41 \mathrm{GPa}$ and the maximum was $100 \mathrm{GPa}$. The most frequently used value of EM was $84.1 \mathrm{GPa}$ in 46 studies (56\%). PR was set at $0.002,0.4$ and $0.23-0.30$ in only one study, 0.2 in two studies, 0.3 in thirty-one studies, 0.33 in forty studies. The minimum value of tensile strength was $10 \mathrm{MPa}$ and the maximum was 48 MPa. The minimum value of compressive strength was $95 \mathrm{MPa}$ and the maximum was $400 \mathrm{MPa}$. The data obtained for density of enamel ranged from 2.14 to $4 \mathrm{~g} \mathrm{~cm}^{-3}$.

For dentin, the minimum value of EM was $10.2 \mathrm{GPa}$ and the maximum was $21 \mathrm{GPa}$. The most frequently used value of EM was 18.6 GPa in 88 studies (70.4\%). PR was set at -0.11-0.07 and 0.33 in only one study, 0.3 in eleven studies, 0.31 in one hundred and three studies, 0.32 in eight studies. The minimum value of tensile strength was $10 \mathrm{MPa}$ and the maximum was $234 \mathrm{MPa}$. The minimum value of compressive strength was $232 \mathrm{MPa}$ and the maximum was $315 \mathrm{MPa}$. The data obtained for density of dentin ranged from 2 to $2.97 \mathrm{~g} \mathrm{~cm}^{-3}$.

For PDL, the minimum value of EM was $0.01 \mathrm{MPa}$ and the maximum was $175 \mathrm{MPa}$. The most frequently used value of EM was $68.9 \mathrm{MPa}$ in 48 studies (55.1\%). PR was set at 0.3 in four studies, 0.45 in fifty-six studies, 0.46 in only one study, and 0.49 in eight studies. The data obtained for density of PDL ranged from 0.95 to $1.10 \mathrm{~g} \mathrm{~cm}^{-3}$. There was no data found for tensile strength or compressive strength.

For pulp tissue (pulp chamber), the minimum value of EM was $0.003 \mathrm{MPa}$ and the maximum was $20 \mathrm{MPa}$. The most frequently used value of EM was $2 \mathrm{MPa}$ in 18 studies (40\%). PR was set at 0.45 in 46 studies. The data obtained for density of the pulp tissue ranged from 1 to $1.1 \mathrm{~g} \mathrm{~cm}^{-3}$. There was no data found about tensile strength or compressive strength.

For cementum, ten different values were used in twelve studies for EM. The minimum value of EM was $2.7 \mathrm{GPa}$ and the maximum was $22.4 \mathrm{GPa}$. PR was set at $0.27,0.322$ and 0.35 in only one study, 0.30 in three studies and 0.31 in five studies. The value of density was $2.03 \mathrm{~g} \mathrm{~cm}^{-3}$, the tensile strength was $29 \mathrm{MPa}$ and the compressive strength was 32.1 MPa in one study. 
For cortical bone, the minimum value of EM was $10 \mathrm{GPa}$ and the maximum was $340 \mathrm{GPa}$. The most frequently used value of EM was $13.7 \mathrm{GPa}$ in forty-nine studies (65.3\%). PR was set at 0.26 in twelve studies, 0.3 in sixty-one studies, 0.32 in two studies, and 0.33 in one study. The tensile strength was $133 \mathrm{MPa}$ in one study. The data obtained for cortical bone ranged from 1.3 to $2 \mathrm{~g} \mathrm{~cm}^{-3}$. There was no data found about compressive strength.

For cancellous bone, the minimum value of EM was $0.056 \mathrm{GPa}$ and the maximum was $13.4 \mathrm{GPa}$. The most frequently used value of EM was $1.37 \mathrm{GPa}$ in fifty-two studies (68.4\%). PR was set at 0.22 in one study, 0.3 in sixty-seven studies, 0.31 in four studies, 0.38 in eight studies. The density data obtained for cancellous bone ranged from 0.7 to $1.87 \mathrm{~g} \mathrm{~cm}^{-3}$. The tensile strength was $75 \mathrm{MPa}$ in one study. There was no data found compressive strength.

Additionally, in consideration of the material data compiled above, the maximum, minimum and mean value of the material properties of teeth were calculated and are represented in Table 2 . The average values were obtained by summing and averaging all the different values collated from the literature.

\section{DISCUSSION}

FEA enables the undertaking of repeatable experiments that do not require ethical approval and design studies can be altered with minimal effort in accordance with the specific requirements (16). However, there are some limitations because it is a computerised approximation of an in vitro study. Furthermore, stress analysis is generally executed under static loading scenarios, and the mechanical properties of teeth are set as isotropic, homogeneous and linearly elastic, even if it does not correspond to in vivo conditions. In addition, over-simplification in geometry could affect the accuracy of the results $(16,17)$.

It is well known that material properties, the functional loading, applied boundary conditions and the geometric detail of the object are the most important factors influencing the predicted accuracy of FEA (4). In this review, the importance of the assignment of proper material properties of teeth, which lay the foundation of the stress and strain measurement, was emphasised.

The reported material property index values vary between different research groups. The EM value for enamel ranged from 41 to $100 \mathrm{GPa}$ in these studies. Zhang et al. explained this variability with possible influence of external factors such as the measuring system used, applied load, nature of samples and direction of enamel rod (18). In another study, it was indicated that EM and hardness of enamel in younger individuals are lower than those of older teeth (19).

Dentin has a more complex structure than enamel. The direction of the dentinal tubules and the collagen fibres and the average density of the mineral phase are the internal factors that affect the mechanical properties of dentin (18). Moreover, it was shown that the mechanical properties of dentin are affected by external factors such as hydration of the environment, as well as internal factors (20). However, no standard technique and measuring environment were discussed.

Measuring the distribution of stress and strain occurring within teeth and PDL is very difficult phenomenon to understand with in vivo experiments. Because of this reason, there are various methods in use, for example laser holography, optoelectronic set-ups, and photoelastic models. It would be true to say that the most commonly utilised and effective method in order to evaluate the stress and strain distribution during active movements is FEA. The different measuring methods, the type of human teeth, the length and shape of the root which influences the formation of PDL, and the humidity of test specimens could lead to obtaining different values for the material properties of a tooth component (21). 
Additionally, in a FEA setup for a tooth deformation, all of the tooth components should be considered, for instance, the exclusion of PDL in a 3D model (because of its relatively lower elasticity properties), where it may not be the main research focus and may seem to complicate the model, it could cause inaccurate results in deformation behaviour and stress distribution of the full model $(16,21)$.

The development of FEA models needs sufficient knowledge of the material properties of the human oral system, most especially the jawbone (mandible). However, determination of appropriate biomechanical properties of living tissues, especially bone tissue in FEA, is still challenging (22). As shown in this study, the wide range of values in the literature for EM also proves this situation. There are many factors that affect the measurement of the mechanical properties of human bony structures including teeth. The structure and scale of human bones are some of these factors, and this can make sampling cubic shape of bone from trabecular regions larger than $5 \mathrm{~mm}$ for compression tests difficult (23). The size and shape of the sample, the storage and loading conditions, the mechanical tests used, the age, sex and systemic disease of the donor, porosity density and mineral content of the sample could also affect the measurements $(22,23)$. In addition, it was shown that mechanical properties of cortical bone changes in an edentulous human mandible (24).

In light of all this information, the most appropriate values for the purpose and methods of the study should be preferred when evaluating the material properties of dental tissues in order to obtain the accurate results that reflect the clinical situation in the FEA to be conducted.

\section{CONCLUSION}

Average ranges for the core material properties for a linear material model to be utilised in a FEA setup such as EM, PR, density and strength values were reviewed and presented. This review revealed that the values of the material parameters varied. The reason for this may be explained with different testing methods, age factor and experience based untested assumptions which are considered by some researchers. Additionally, a specific value for a specific tooth component may not be obtained due to the organic structure of human teeth components. It was also shown that the material properties of dental tissues in some of the research papers related to FEA studies were usually quoted from previous FEA studies, and there were very few studies in which in vitro evaluation of the mechanical properties of dental tissues was performed. The data reviewed in this paper related to linear material models to be utilised in a FEA would provide an understanding of the range in magnitudes of the specific material properties of the tooth components which should be carefully evaluated and adopted by researchers in dentistry. The average ranges were calculated in this paper in order to frame a general perspective for the values for specific tooth components. The literature search also indicated that experience in FEA setup in order to simulate real-life responses in deformation analysis is essential. Finally, it was specifically concluded that comprehensive and up-to-date physical material testing studies are required in order to obtain reliable material data for realisation of accurate finite element studies in dentistry.

\section{ACKNOWLEDGEMENT}

This research was partly supported financially by The Scientific Research Projects Coordination Unit of Akdeniz University (Antalya-Turkey). The authors declare that there is no conflict of interest to disclose and they have no known competing financial interests or personal relationships that could have appeared to influence the work reported in this paper. 


\section{REFERENCES}

1. Piccioni MAR V, Campos EA, Saad JRC, de Andrade MF, Galvão MR, Abi Rached A. Application of the finite element method in Dentistry. RSBO Rev Sul-Brasileira Odontol. 2013;10(4):369-77.

2. Gomes EA, Diana HH, Oliveira JS, Silva-Sousa YTC, Faria ACL, Ribeiro RF. Reliability of FEA on the results of mechanical properties of materials. Braz Dent J. 2015;26(6):667-70.

3. Weinstein AM, Klawitter JJ, Anand SC, Schuessler R. Stress analysis of porous rooted dental implants. J Dent Res. 1976;55(5):772-7.

4. Choi AH, Conway RC, Ben-Nissan B. Finite-element modeling and analysis in nanomedicine and dentistry. Nanomedicine. 2014;9(11):1681-95.

5. Musani I, Prabhakar AR. Biomechanical stress analysis of mandibular first permanent molar; restored with amalgam and composite resin: A Computerized finite element study. Int J Clin Pediatr Dent. 2010;3(1):5.

6. Korioth TWP, Versluis A. Modeling the mechanical behavior of the jaws and their related structures by finite element (FE) analysis. Crit Rev Oral Biol Med. 1997;8(1):90-104.

7. Wu Z, Ovaert TC, Niebur GL. Viscoelastic properties of human cortical bone tissue depend on gender and elastic modulus. J Orthop Res [Internet]. 2012 May 1 [cited 2020 Sep 25];30(5):693-9. Available from: http://doi.wiley.com/10.1002/jor.22001

8. LeMaitre J. Introduction to Viscoplasticity. In: Handbook of Materials Behavior Models. Elsevier; 2001. p. $301-2$.

9. Yamashita J, Li X, Furman BR, Rawls HR, Wang X, Agrawal CM. Collagen and bone viscoelasticity: A dynamic mechanical analysis. J Biomed Mater Res [Internet]. 2002 Jan 1 [cited 2020 Sep 25];63(1):31-6. Available from: http://doi.wiley.com/10.1002/jbm.10086

10. Morgan EF, Unnikrisnan GU, Hussein AI. Bone Mechanical Properties in Healthy and Diseased States. Annu Rev Biomed Eng [Internet]. 2018 Jun 4 [cited 2020 Sep 25];20(1):119-43. Available from: https://www.annualreviews.org/doi/10.1146/annurev-bioeng-062117-121139

11. Hambli R. A quasi-brittle continuum damage finite element model of the human proximal femur based on element deletion. Med Biol Eng Comput [Internet]. 2013 Feb 21 [cited 2020 Sep 25];51(1-2):219-31. Available from: https://link.springer.com/article/10.1007/s11517-012-0986-5

12. Novitskaya E, Chen P-Y, Hamed E, Jun L, Lubarda V, Jasiuk I, et al. Recent advances on the measurement and calculation of the elastic moduli of cortical and trabecular bone: A review. Theor Appl Mech [Internet]. 2011 [cited 2020 Sep 25];38(3):209-97. Available from: https://ui.adsabs.harvard.edu/abs/2011TAM....38..209N/abstract

13. Cammarata M, Nicoletti F, Di Paola M, Valenza A, Zummo G. Mechanical behavior of human bones with different saturation levels. In Montreal, QC.: 2nd International Electronic Conference on Materials (MDPI AG); 2016. p. B003.

14. Wirtz DC, Schiffers N, Forst R, Pandorf T, Weichert D, Radermacher K. Critical evaluation of known bone material properties to realize anisotropic FE-simulation of the proximal femur. J Biomech. 2000 Oct 
1;33(10):1325-30.

15. Khan SN, Warkhedkar RM, Shyam AK. Human bone strength evaluation through different mechanical tests. Int J Curr Eng Technol. 2014;2:539-43.

16. Trivedi S. Finite element analysis: A boon to dentistry. J oral Biol craniofacial Res. 2014;4(3):200-3.

17. Reddy MS, Sundram R, Abdemagyd HAE. Application of finite element model in implant dentistry: A systematic review. J Pharm Bioallied Sci. 2019;11(Suppl 2):S85.

18. Zhang Y-R, Du W, Zhou X-D, Yu H-Y. Review of research on the mechanical properties of the human tooth. Int J Oral Sci. 2014;6(2):61-9.

19. Park S, Wang DH, Zhang D, Romberg E, Arola D. Mechanical properties of human enamel as a function of age and location in the tooth. J Mater Sci Mater Med. 2008;19(6):2317-24.

20. Kinney JH, Gladden JR, Marshall GW e al, Marshall SJ, So JH, Maynard JD. Resonant ultrasound spectroscopy measurements of the elastic constants of human dentin. J Biomech. 2004;37(4):437-41.

21. Minch L. Material properties of periodontal ligaments. Postep Hig Med Dosw. 2013;67(67):1261-4.

22. Odin G, Savoldelli C, Bouchard P-O, Tillier Y. Determination of Young's modulus of mandibular bone using inverse analysis. Med Eng Phys. 2010;32(6):630-7.

23. Lakatos É, Magyar L, Bojtár I. Material properties of the mandibular trabecular bone. J Med Eng. 2014;2014.

24. Schwartz-Dabney CL, Dechow PC. Edentulation alters material properties of cortical bone in the human mandible. J Dent Res. 2002;81(9):613-7.

25. Vanlıoğlu B, Özkan K, Uçankale M, Cansız E, Kayabaşı O. Effect of post material, cement and amount of coronal destruction on stress distribution: 3D FEA study. Balk J Stomatol. 2013;17(1):18-25.

26. Bessone LM, Bodereau EF, Cabanillas G, Dominguez A. Analysis of biomechanical behaviour of anterior teeth using two different methods: Finite element method and experimental tests. Engineering. 2014;2014.

27. Rubin C, Krishnamurthy N, Capilouto E, Yi H. Stress analysis of the human tooth using a three-dimensional finite element model. J Dent Res. 1983;62(2):82-6.

28. Durmuş B, Hale AA, Oğuz E, Sema B. The effect of different irrigation protocols on elastic modulus of dentine and biomechanics of single- rooted premolar tooth: A nano- iIndentation and finite element analysis study. Niger J Clin Pract. 2019;22(1).

29. Hasan I, Frentzen M, Utz K-H, Hoyer D, Langenbach A, Bourauel C. Finite element analysis of adhesive endocrowns of molars at different height levels of buccally applied load. J Dent Biomech. 2012;3.

30. Ersöz E. Evaluation of stresses caused by dentin pin with finite elements stress analysis method. J Oral Rehabil. 2000;27(9):769-73.

31. Ozkurt-Kayahan Z, Turgut B, Akin H, Kayahan MB, Kazazoglu E. A 3D finite element analysis of stress distribution on different thicknesses of mineral trioxide aggregate applied on various sizes of pulp perforation. Clin Oral Investig. 2020;24(10):3477-83. 
32. Askerbeyli Örs S, Aksel H, Küçükkaya Eren S, Serper A. Effect of perforation size and furcal lesion on stress distribution in mandibular molars: a finite element analysis. Int Endod J. 2019;52(3):377-84.

33. Jang Y, Hong H-T, Roh B-D, Chun H-J. Influence of apical root resection on the biomechanical response of a single-rooted tooth: a 3-dimensional finite element analysis. J Endod. 2014;40(9):1489-93.

34. Verri FR, Pellizzer EP, Pereira JA, Zuim PRJ, Júnior JFS. Evaluation of bone insertion level of support teeth in class I mandibular removable partial denture associated with an osseointegrated implant: a study using finite element analysis. Implant Dent. 2011;20(3):192-201.

35. Santos AF V, Tanaka CB, Lima RG, Espósito COM, Ballester RY, Braga RR, et al. Vertical root fracture in upper premolars with endodontic posts: finite element analysis. J Endod. 2009;35(1):117-20.

36. Davy DT, Dilley GL, Krejci RF. Determination of stress patterns in root-filled teeth incorporating various dowel designs. J Dent Res. 1981;60(7):1301-10.

37. Toparli M, Gökay N, Aksoy T. Analysis of a restored maxillary second premolar tooth by using threedimensional finite element method. J Oral Rehabil. 1999;26(2):157-64.

38. Bergoli CD, Meira JBC, Valandro LF, Bottino MA. Survival rate, load to fracture, and finite element analysis of incisors and canines restored with ceramic veneers having varied preparation design. Oper Dent. 2014;39(5):530-40.

39. Yaman SD, Alaçam T, Yaman Y. Analysis of stress distribution in a vertically condensed maxillary central incisor root canal. J Endod. 1995;21(6):321-5.

40. Versluis A, Tantbirojn D, Douglas WH. Do dental composites always shrink toward the light? J Dent Res. 1998;77(6):1435-45.

41. Stanford JW, Weigel K V, Paffenbarger GC, Sweeney WT. Compressive properties of hard tooth tissues and some restorative materials. J Am Dent Assoc. 1960;60(6):746-56.

42. Mahmoudi M, Saidi A, Nassab SAG, Hashemipour MA. A three-dimensional finite element analysis of the effects of restorative materials and post geometry on stress distribution in mandibular molar tooth restored with post-core crown. Dent Mater J. 2012;1203190241.

43. Yamanel K, Çaglar A, GÜLSAHI K, Özden UA. Effects of different ceramic and composite materials on stress distribution in inlay and onlay cavities: 3-D finite element analysis. Dent Mater J. 2009;28(6):661-70.

44. Dejak B, Mlotkowski A. Three-dimensional finite element analysis of strength and adhesion of composite resin versus ceramic inlays in molars. J Prosthet Dent. 2008;99(2):131-40.

45. Naveh GRS, Chattah NL-T, Zaslansky P, Shahar R, Weiner S. Tooth-PDL-bone complex: Response to compressive loads encountered during mastication-A review. Arch Oral Biol. 2012;57(12):1575-84.

46. Huang H-M, Ou K-L, Wang W-N, Chiu W-T, Lin C-T, Lee S-Y. Dynamic finite element analysis of the human maxillary incisor under impact loading in various directions. J Endod. 2005;31(10):723-7.

47. Lee S, Huang H, Lin C, Shih Y. In vivo and in vitro natural frequency analysis of periodontal conditions: An innovative method. J Periodontol. 2000;71(4):632-40. 
48. Huang H-M, Tsai C-Y, Lee H-F, Lin C-T, Yao W-C, Chiu W-T, et al. Damping effects on the response of maxillary incisor subjected to a traumatic impact force: a nonlinear finite element analysis. J Dent. 2006;34(4):261-8.

49. Moga RA, Chiorean CG. Periodontal ligament stress analysis during periodontal resorption. In: London: Proceedings of the World Congress on Engineering. 2016. p. 1-6.

50. Couegnat G, Fok SL, Cooper JE, Qualtrough AJE. Structural optimization of dental restorations using the principle of adaptive growth. Dent Mater. 2006;22(1):3-12.

51. Andreaus U, Colloca M, Iacoviello D. Coupling image processing and stress analysis for damage identification in a human premolar tooth. Comput Methods Programs Biomed. 2011;103(2):61-73.

52. Rees JS, Jacobsen PH. Elastic modulus of the periodontal ligament. Biomaterials. 1997;18(14):995-9.

53. Rees JS, Hammadeh M, Jagger DC. Abfraction lesion formation in maxillary incisors, canines and premolars: a finite element study. Eur J Oral Sci. 2003;111(2):149-54.

54. Moga RA, Chiorean CG. Strain analysis of a human tooth with support tissues resorption. In: Proceedings of the World Congress on Engineering. 2013.

55. Kowalczyk P. Influence of the shape of the layers in photo-cured dental restorations on the shrinkage stress peaks_FEM study. Dent Mater. 2009;25(12):e83-91.

56. Durmuş G, Oyar P. Effects of post core materials on stress distribution in the restoration of mandibular second premolars: a finite element analysis. J Prosthet Dent. 2014;112(3):547-54.

57. Farah JW, Hood Jaa, Craig RG. Effects of cement bases on the stresses in amalgam restorations. J Dent Res. $1975 ; 54(1): 10-5$.

58. Dejak B, Młotkowski A, Romanowicz M. Finite element analysis of stresses in molars during clenching and mastication. J Prosthet Dent. 2003;90(6):591-7.

59. Farah JW, Craig RG, Meroueh KA. Finite element analysis of a mandibular model. J Oral Rehabil. 1988;15(6):615-24.

60. Lin C-L, Chang Y-H, Pai C-A. Evaluation of failure risks in ceramic restorations for endodontically treated premolar with MOD preparation. Dent Mater. 2011;27(5):431-8.

61. Chuang S-F, Huang P-S, Chen TY-F, Huang L-H, Su K-C, Chang C-H. Shrinkage behaviors of dental composite restorations-The experimental-numerical hybrid analysis. Dent Mater. 2016;32(12):e362-73.

62. Burak Özcelik T, Ersoy E, Yilmaz B. Biomechanical Evaluation of Tooth- and Implant- Supported Fixed Dental Prostheses with Various Nonrigid Connector Positions: A Finite Element Analysis. J Prosthodont Implant Esthet Reconstr Dent. 2011;20(1):16-28.

63. Winkler MM, Katona TR, Paydar NH. Finite element stress analysis of three filling techniques for class V lightcured composite restorations. J Dent Res. 1996;75(7):1477-83.

64. Ricks-Williamson LJ, Fotos PG, Goel VK, Spivey JD, Rivera EM, Khera SC. A three-dimensional finiteelement stress analysis of an endodontically prepared maxillary central incisor. J Endod. 1995;21(7):362-7. 
65. McGuinness N, Wilson AN, Jones M, Middleton J, Robertson NR. Stresses induced by edgewise appliances in the periodontal ligament — a finite element study. angle Orthod. 1992;62(1):15-22.

66. Chang Y-H, Lee H, Lin C-L. Early resin luting material damage around a circular fiber post in a root canal treated premolar by using micro-computerized tomographic and finite element sub-modeling analyses. J Mech Behav Biomed Mater. 2015;51:184-93.

67. Allen C, Meyer CA, Yoo E, Vargas JA, Liu Y, Jalali P. Stress distribution in a tooth treated through minimally invasive access compared to one treated through traditional access: A finite element analysis study. J Conserv Dent JCD. 2018;21(5):505.

68. Zhu J, Rong Q, Wang X, Gao X. Influence of remaining tooth structure and restorative material type on stress distribution in endodontically treated maxillary premolars: A finite element analysis. J Prosthet Dent. 2017;117(5):646-55.

69. Hsu M-L, Chang C-L. Application of finite element analysis in dentistry. Finite Elem Anal. 2010;44-60.

70. Davide A, Raffaella A, Marco T, Michele S, Syed J, Massimo M, et al. Direct restoration modalities of fractured central maxillary incisors: A multi-levels validated finite elements analysis with in vivo strain measurements. Dent Mater. 2015;31(12):e289-305.

71. Saber SM, Hayaty DM, Nawar NN, Kim H-C. The Effect of Access Cavity Designs and Sizes of Root Canal Preparations on the Biomechanical Behavior of an Endodontically Treated Mandibular First Molar: A Finite Element Analysis. J Endod. 2020;

72. Lin J, Lin Z, Zheng Z. Effect of different restorative crown design and materials on stress distribution in endodontically treated molars: A finite element analysis study. 2020;

73. Hollanders ACC, Kuper NK, Huysmans M, Versluis A. The effect of occlusal loading on cervical gap deformation: A 3D finite element analysis. Dent Mater. 2020;

74. Rodrigues M de P, SOARES PBF, GOMES MAB, Pereira RA, Tantbirojn D, Versluis A, et al. Direct resin composite restoration of endodontically-treated permanent molars in adolescents: bite force and patient-specific finite element analysis. J Appl Oral Sci. 2020;28.

75. Oenning AC, Freire AR, Rossi AC, Prado FB, Caria PHF, Correr-Sobrinho L, et al. Resorptive potential of impacted mandibular third molars: 3D simulation by finite element analysis. Clin Oral Investig.

2018;22(9):3195-203.

76. Sarrafpour B, Swain M, Li Q, Zoellner H. Tooth eruption results from bone remodelling driven by bite forces sensed by soft tissue dental follicles: a finite element analysis. PLoS One. 2013;8(3):e58803.

77. Jiang Q, Huang Y, Tu X, Li Z, He Y, Yang X. Biomechanical properties of first maxillary molars with different endodontic cavities: a finite element analysis. J Endod. 2018;44(8):1283-8.

78. MARAVIĆ T, VASILJEVIĆ D, Kantardžić I, Lainović T, Lužanin O, Blažić L. Influence of restorative procedures on endodontically treated premolars: Finite element analysis of a CT-scan based three-dimensional model. Dent Mater J. 2018;2017-64.

79. Yang H, Park C, Shin J-H, Yun K-D, Lim H-P, Park S-W, et al. Stress distribution in premolars restored with 
inlays or onlays: 3D finite element analysis. J Adv Prosthodont. 2018;10(3):184-90.

80. Yuan K, Niu C, Xie Q, Jiang W, Gao L, Ma R, et al. Apical stress distribution under vertical compaction of gutta- percha and occlusal loads in canals with varying apical sizes: a three- dimensional finite element analysis. Int Endod J. 2018;51(2):233-9.

81. Koycu BC, Imirzalioglu P. Heat transfer and thermal stress analysis of a mandibular molar tooth restored by different indirect restorations using a three-dimensional finite element method. J Prosthodont Esthet Reconstr Dent. 2017;26(5):460-73.

82. Bonessio N, Arias A, Lomiento G, Peters OA. Effect of root canal treatment procedures with a novel rotary nickel titanium instrument (TRUShape) on stress in mandibular molars: a comparative finite element analysis. Odontology. 2017;105(1):54-61.

83. Yuan K, Niu C, Xie Q, Jiang W, Gao L, Huang Z, et al. Comparative evaluation of the impact of minimally invasive preparation vs. conventional straight- line preparation on tooth biomechanics: a finite element analysis. Eur J Oral Sci. 2016;124(6):591-6.

84. KÖYCÜ BÇ, İMIRZALIOĞLU P, Oezden UA. Three-dimensional finite element analysis of stress distribution in inlay-restored mandibular first molar under simultaneous thermomechanical loads. Dent Mater J.

2016;35(2):180-6.

85. Jones ML, Hickman J, Middleton J, Knox J, Volp C. A validated finite element method study of orthodontic tooth movement in the human subject. J Orthod. 2001;28(1):29-38.

86. Tanaka OM, Araújo EA, Oliver DR, Behrents RG. A finite element analysis of the maxillary first molar PDL with maxillary protraction in a mixed dentition Class III malocclusion. Orthod Craniofac Res. 2015;18(4):24250.

87. Zelic K, Vukicevic A, Jovicic G, Aleksandrovic S, Filipovic N, Djuric M. Mechanical weakening of devitalized teeth: three- dimensional Finite Element Analysis and prediction of tooth fracture. Int Endod J. 2015;48(9):850-63.

88. Benazzi S, Grosse IR, Gruppioni G, Weber GW, Kullmer O. Comparison of occlusal loading conditions in a lower second premolar using three-dimensional finite element analysis. Clin Oral Investig. 2014;18(2):369-75.

89. Er O, Kilic K, Esim E, Aslan T, Kilinc HI, Yildirim S. Stress distribution of oval and circular fiber posts in amandibular premolar: a three-dimensional finite element analysis. J Adv Prosthodont. 2013;5(4):434-9.

90. Dejak B, Młotkowski A. Finite element analysis of strength and adhesion of cast posts compared to glass fiberreinforced composite resin posts in anterior teeth. J Prosthet Dent. 2011;105(2):115-26.

91. Lin C, Chang Y, Chang C, Pai C, Huang S. Finite element and Weibull analyses to estimate failure risks in the ceramic endocrown and classical crown for endodontically treated maxillary premolar. Eur J Oral Sci.

2010;118(1):87-93.

92. Chatvanitkul C, Lertchirakarn V. Stress distribution with different restorations in teeth with curved roots: a finite element analysis study. J Endod. 2010;36(1):115-8.

93. Jiang W, Bo H, Yongchun G, LongXing N. Stress distribution in molars restored with inlays or onlays with or 
without endodontic treatment: a three-dimensional finite element analysis. J Prosthet Dent. 2010;103(1):6-12.

94. Ou K, Chang C, Chang W, Lin C, Chang K, Huang H. Effect of damping properties on fracture resistance of root filled premolar teeth: a dynamic finite element analysis. Int Endod J. 2009;42(8):694-704.

95. Cheng R, Zhou X, Liu Z, Yang H, Gao Q, Hu T. Finite element analysis of the effects of three preparation techniques on stresses within roots having curved canals. Int Endod J. 2009;42(3):220-6.

96. Middleton J, Jones M, Wilson A. The role of the periodontal ligament in bone modeling: the initial development of a time-dependent finite element model. Am J Orthod Dentofac Orthop. 1996;109(2):155-62.

97. Lin C-L, Chang Y-H, Liu P-R. Multi-factorial analysis of a cusp-replacing adhesive premolar restoration: a finite element study. J Dent. 2008;36(3):194-203.

98. Magne P, Tan DT. Incisor compliance following operative procedures: a rapid 3-D finite element analysis using micro-CT data. J Adhes Dent. 2008;10(1).

99. Cheng R, Zhou X-D, Liu Z, Hu T. Development of a finite element analysis model with curved canal and stress analysis. J Endod. 2007;33(6):727-31.

100. Zarone F, Sorrentino R, Apicella D, Valentino B, Ferrari M, Aversa R, et al. Evaluation of the biomechanical behavior of maxillary central incisors restored by means of endocrowns compared to a natural tooth: a 3D static linear finite elements analysis. Dent Mater. 2006;22(11):1035-44.

101. Zarone F, Apicella D, Sorrentino R, Ferro V, Aversa R, Apicella A. Influence of tooth preparation design on the stress distribution in maxillary central incisors restored by means of alumina porcelain veneers: a 3D-finite element analysis. Dent Mater. 2005;21(12):1178-88.

102. Lin C, Chang C, Ko C. Multifactorial analysis of an MOD restored human premolar using auto- mesh finite element approach. J Oral Rehabil. 2001;28(6):576-85.

103. Fenner DN, Robinson PB, Cheung P-Y. Three-dimensional finite element analysis of thermal shock in a premolar with a composite resin MOD restoration. Med Eng Phys. 1998;20(4):269-75.

104. Dal Piva AM de O, Tribst JPM, e Souza RO de A, Borges ALS. Influence of alveolar bone loss and cement layer thickness on the biomechanical behavior of endodontically treated maxillary incisors: a 3-dimensional finite element analysis. J Endod. 2017;43(5):791-5.

105. Dejak B, Młotkowski A, Langot C. Three-dimensional finite element analysis of molars with thin-walled prosthetic crowns made of various materials. Dent Mater. 2012;28(4):433-41.

106. Singh SV, Bhat M, Gupta S, Sharma D, Satija H, Sharma S. Stress distribution of endodontically treated teeth with titanium alloy post and carbon fiber post with different alveolar bone height: A three-dimensional finite element analysis. Eur J Dent. 2015;9(3):428.

107. Atmaram GH, Mohammed H. Estimation of physiologic stresses with a natural tooth considering fibrous PDL structure. J Dent Res. 1981;60(5):873-7.

108. Zhou ZR, Zheng J. Tribology of dental materials: a review. J Phys D Appl Phys. 2008;41(11):113001.

109. Wright KWJ, Yettram AL. Reactive force distributions for teeth when loaded singly and when used as fixed 
partial denture abutments. J Prosthet Dent. 1979;42(4):411-6.

110. Vilela ABF, Soares PBF, Almeida GA, Veríssimo C, Rodrigues MP, Versluis A, et al. Three- dimensional finite element stress analysis of teeth adjacent to a traumatized incisor. Dent Traumatol. 2019;35(2):128-34.

111. Belli S, Eraslan O, Eskitascioglu G. Effect of root filling on stress distribution in premolars with endodonticperiodontal lesion: a finite elemental analysis study. J Endod. 2016;42(1):150-5.

112. Aslan T, Üstün Y, Esim E. Stress distributions in internal resorption cavities restored with different materials at different root levels: a finite element analysis study. Aust Endod J. 2019;45(1):64-71.

113. Farah JW, Craig RG, Meroueh KA. Finite element analysis of three- and four- unit bridges. J Oral Rehabil. 1989;16(6):603-11.

114. Chang Y-H, Wang H-W, Lin P-H, Lin C-L. Evaluation of early resin luting cement damage induced by voids around a circular fiber post in a root canal treated premolar by integrating micro-CT, finite element analysis and fatigue testing. Dent Mater. 2018;34(7):1082-8.

115. Kim S, Chen D, Park S-Y, Lee C-J, Kim H-C, Kim E. Stress Analyses of Retrograde Cavity Preparation Designs for Surgical Endodontics in the Mesial Root of the Mandibular Molar: A Finite Element AnalysisPart II. J Endod. 2020;

116. Ichim I, Kuzmanovic D V, Love RM. A finite element analysis of ferrule design on restoration resistance and distribution of stress within a root. Int Endod J. 2006;39(6):443-52.

117. Peyton F, Mahler DB, Hershenov B. Physical properties of dentin. J Dent Res. 1952;31(3):366-70.

118. Romeed SA, Fok SL, Wilson NHF. A comparison of 2D and 3D finite element analysis of a restored tooth. J Oral Rehabil. 2006;33(3):209-15.

119. Roscoe MG, Noritomi PY, Novais VR, Soares CJ. Influence of alveolar bone loss, post type, and ferrule presence on the biomechanical behavior of endodontically treated maxillary canines: strain measurement and stress distribution. J Prosthet Dent. 2013;110(2):116-26.

120. Eraslan O, Sevimay M, Usumez A, Eskitascioglu G. Effects of cantilever design and material on stress distribution in fixed partial dentures-a finite element analysis. J Oral Rehabil. 2005;32(4):273-8.

121. Değer Y, Adigüzel Ö, Özer SY, Kaya S, Polat ZS, Bozyel B. Evaluation of temperature and stress distribution on 2 different post systems using 3-dimensional finite element analysis. Med Sci Monit Int Med J Exp Clin Res. $2015 ; 21: 3716$.

122. Yoon HG, Oh HK, Lee D-Y, Shin J-H. 3-D finite element analysis of the effects of post location and loading location on stress distribution in root canals of the mandibular 1st molar. J Appl Oral Sci. 2018;26.

123. Reinhardt RA, Pao YC, Krejci RF. Periodontal ligament stresses in the initiation of occlusal traumatism. J Periodontal Res. 1984;19(3):238-46.

124. de Paula Rodrigues M, Soares PBF, Valdivia ADCM, Pessoa RS, Veríssimo C, Versluis A, et al. Patientspecific finite element analysis of fiber post and ferrule design. J Endod. 2017;43(9):1539—44.

125. Eskitaşcıoğlu G, Belli S, Kalkan M. Evaluation of two post core systems using two different methods (fracture 
strength test and a finite elemental stress analysis). J Endod. 2002;28(9):629-33.

126. Reinhardt RA, Krejci RF, Pao YC, Stannard JG. Dentin stresses in post-reconstructed teeth with diminishing bone support. J Dent Res. 1983;62(9):1002-8.

127. Gomes ÉA, Gueleri DB, da Silva SRC, Ribeiro RF, Silva-Sousa YTC. Three-dimensional finite element analysis of endodontically treated teeth with weakened radicular walls restored with different protocols. J Prosthet Dent. 2015;114(3):383-9.

128. Holmes DC, Diaz-Arnold AM, Leary JM. Influence of post dimension on stress distribution in dentin. J Prosthet Dent. 1996;75(2):140-7.

129. Toparli M. Stress analysis in a post- restored tooth utilizing the finite element method. J Oral Rehabil. 2003;30(5):470-6.

130. Lanza A, Aversa R, Rengo S, Apicella D, Apicella A. 3D FEA of cemented steel, glass and carbon posts in a maxillary incisor. Dent Mater. 2005;21(8):709-15.

131. Asmussen E, Peutzfeldt A, Sahafi A. Finite element analysis of stresses in endodontically treated, dowelrestored teeth. J Prosthet Dent. 2005;94(4):321-9.

132. LI L, Wang Z, Bai Z, Yong M, Bo G, Xin H, et al. Three-dimensional finite element analysis of weakened roots restored with different cements in combination with titanium alloy posts. Chin Med J (Engl). 2006;119(4):30511.

133. Jiang F, Xia Z, Li S, Eckert G, Chen J. Mechanical environment change in root, periodontal ligament, and alveolar bone in response to two canine retraction treatment strategies. Orthod Craniofac Res. 2015;18:29-38.

134. Chieruzzi M, Pagano S, Cianetti S, Lombardo G, Kenny JM, Torre L. Effect of fibre posts, bone losses and fibre content on the biomechanical behaviour of endodontically treated teeth: 3D-finite element analysis. Mater Sci Eng C. 2017;74:334-46.

135. Corrêa G, Brondani LP, Wandscher VF, Pereira GKR, Valandro LF, Bergoli CD. Influence of remaining coronal thickness and height on biomechanical behavior of endodontically treated teeth: survival rates, load to fracture and finite element analysis. J Appl Oral Sci. 2018;26.

136. Falakaloğlu S, Adıgüzel Ö, Özdemir G. Root canal reconstruction using biological dentin posts: A 3D finite element analysis. J Dent Res Dent Clin Dent Prospects. 2019;13(4):274.

137. Da Fonseca GF, De Andrade GS, Dal Piva AM de O, Tribst JPM, Borges ALS. Computer-aided design finite element modeling of different approaches to rehabilitate endodontically treated teeth. J Indian Prosthodont Soc. 2018;18(4):329.

138. Okamoto K, Ino T, Iwase N, Shimizu E, Suzuki M, Satoh G, et al. Three-dimensional finite element analysis of stress distribution in composite resin cores with fiber posts of varying diameters. Dent Mater J. 2008;27(1):4955.

139. Kumar P, Rao RN. Three-dimensional finite element analysis of stress distribution in a tooth restored with metal and fiber posts of varying diameters: An in-vitro study. J Conserv Dent JCD. 2015;18(2):100. 
140. Dartora NR, de Conto Ferreira MB, Moris ICM, Brazão EH, Spazin AO, Sousa-Neto MD, et al. Effect of intracoronal depth of teeth restored with endocrowns on fracture resistance: in vitro and 3-dimensional finite element analysis. J Endod. 2018;44(7):1179-85.

141. Mahmoudi M, Saidi AR, Amini P, Hashemipour MA. Influence of inhomogeneous dental posts on stress distribution in tooth root and interfaces: Three-dimensional finite element analysis. J Prosthet Dent. 2017;118(6):742-51.

142. Wang CH, Du JK, Li HY, Chang HC, Chen KK. Factorial analysis of variables influencing mechanical characteristics of a post used to restore a root filled premolar using the finite element stress analysis combined with the Taguchi method. Int Endod J. 2016;49(7):690-9.

143. Liu S, Liu Y, Xu J, Rong Q, Pan S. Influence of occlusal contact and cusp inclination on the biomechanical character of a maxillary premolar: a finite element analysis. J Prosthet Dent. 2014;112(5):1238-45.

144. Romeed SA, Dunne SM. Stress analysis of different post- luting systems: a three- dimensional finite element analysis. Aust Dent J. 2013;58(1):82-8.

145. Jang J-H, Park S-J, Min K-S, Lee B-N, Chang H-S, Oh W-M, et al. Stress behavior of cemented fiberreinforced composite and titanium posts in the upper central incisor according to the post length: Twodimensional finite element analysis. J Dent Sci. 2012;7(4):384-9.

146. Al-Omiri MK, Rayyan MR, Abu-Hammad O. Stress analysis of endodontically treated teeth restored with postretained crowns: A finite element analysis study. J Am Dent Assoc. 2011;142(3):289-300.

147. Fu G, Deng F, Wang L, Ren A. The three- dimension finite element analysis of stress in posterior tooth residual root restored with postcore crown. Dent Traumatol. 2010;26(1):64-9.

148. Çağlar A, Bal BT, Aydin C, Yilmaz H, Özkan S. Evaluation of stresses occurring on three different zirconia dental implants: three-dimensional finite element analysis. Int J Oral Maxillofac Implants. 2010;25(1).

149. Lin C, Wang J, Chang S, Chen S. Evaluation of Stress Induced by Implant Type, Number of Splinted Teeth, and Variations in Periodontal Support in Tooth- Implant-Supported Fixed Partial Dentures: A Non- Linear Finite Element Analysis. J Periodontol. 2010;81(1):121-30.

150. HSU M, CHEN C, CHEN B, HUANG H, CHANG C. Effects of post materials and length on the stress distribution of endodontically treated maxillary central incisors: a 3D finite element analysis. J Oral Rehabil. 2009;36(11):821-30.

151. Eraslan O, Aykent F, Yücel MT, Akman S. The finite element analysis of the effect of ferrule height on stress distribution at post-and-core-restored all-ceramic anterior crowns. Clin Oral Investig. 2009;13(2):223-7.

152. Lin C, Wang J, Chang W. Biomechanical interactions in tooth-implant- supported fixed partial dentures with variations in the number of splinted teeth and connector type: a finite element analysis. Clin Oral Implants Res. 2008;19(1):107-17.

153. He Y, Hasan I, Keilig L, Chen J, Pan Q, Huang Y, et al. Combined implant-residual tooth supported prosthesis after tooth hemisection: A finite element analysis. Ann Anatomy-Anatomischer Anzeiger. 2016;206:96-103.

154. Thresher RW, Saito GE. The stress analysis of human teeth. J Biomech. 1973;6(5):443-9. 
155. Weinstein AM, Klawitter JJ, Cook SD. Implant- bone interface characteristics of bioglass dental implants. J Biomed Mater Res. 1980;14(1):23-9.

156. Han T, Chen K, Cao R, Zheng T, Chen Z, Zhang X, et al. Influence of post- core material and cement peculiarities on stress of post- cores under ultrasonic vibration: a three- dimensional finite element analysis. Int Endod J. 2020;

157. Soares CJ, Raposo LHA, Soares PV, Santos- Filho PCF, Menezes MS, Soares PBF, et al. Effect of Different Cements on the Biomechanical Behavior of Teeth Restored with Cast Dowel- and- Cores-In Vitro and FEA Analysis. J Prosthodont Implant Esthet Reconstr Dent. 2010;19(2):130-7.

158. Chen A, Feng X, Zhang Y, Liu R, Shao L. Finite element analysis of stress distribution in four different endodontic post systems in a model canine. Biomed Mater Eng. 2015;26(s1):S629-35.

159. Gröning F, Fagan MJ, O’Higgins P. The effects of the periodontal ligament on mandibular stiffness: a study combining finite element analysis and geometric morphometrics. J Biomech. 2011;44(7):1304-12.

160. Ueno S, Motoyoshi M, Mayahara K, Saito Y, Akiyama Y, Son S, et al. Analysis of a force system for upper molar distalization using a trans-palatal arch and mini-implant: a finite element analysis study. Eur J Orthod. 2013;35(5):628-33.

161. Cattaneo PM, Dalstra M, Melsen B. The finite element method: a tool to study orthodontic tooth movement. J Dent Res. 2005;84(5):428-33.

162. Gerami A, Dadgar S, Rakhshan V, Jannati P, Sobouti F. Displacement and force distribution of splinted and tilted mandibular anterior teeth under occlusal loads: an in silico 3D finite element analysis. Prog Orthod. 2016;17(1):16.

163. Widera GEO, Tesk JA, Privitzer E. Interaction effects among cortical bone, cancellous bone, and periodontal membrane of natural teeth and implants. J Biomed Mater Res. 1976;10(4):613-23.

164. Tanne K, Sakuda M, Burstone CJ. Three-dimensional finite element analysis for stress in the periodontal tissue by orthodontic forces. Am J Orthod Dentofac Orthop. 1987;92(6):499-505.

165. Ruse ND. Propagation of erroneous data for the modulus of elasticity of periodontal ligament and gutta percha in FEM/FEA papers: a story of broken links. Dent Mater. 2008;24(12):1717-9.

166. Memon S, Mehta S, Salim Malik NN, Sharma D, Arora H. Three-dimensional finite element analysis of the stress distribution in the endodontically treated maxillary central incisor by glass fiber post and dentin post. $\mathbf{J}$ Indian Prosthodont Soc. 2016;16(1):70.

167. Poppe M, Bourauel C, Jäger A. Determination of the elasticity parameters of the human periodontal ligament and the location of the center of resistance of single-rooted teeth a study of autopsy specimens and their conversion into finite element models. J Orofac Orthop der Kieferorthopädie. 2002;63(5):358-70.

168. Gloria A, Maietta S, Martorelli M, Lanzotti A, Watts DC, Ausiello P. FE analysis of conceptual hybrid composite endodontic post designs in anterior teeth. Dent Mater. 2018;34(7):1063-71.

169. Craig RG, Peyton FA, Johnson DW. Compressive properties of enamel, dental cements, and gold. J Dent Res. 1961;40(5):936-45. 
170. Bucchi C, Marcé- Nogué J, Galler KM, Widbiller M. Biomechanical performance of an immature maxillary central incisor after revitalization: a finite element analysis. Int Endod J. 2019;52(10):1508-18.

171. De Santis R, Ambrosio L, Nicolais L. Mechanical properties of tooth structures. In: Integrated biomaterials science. Springer; 2002. p. 589-99.

172. Qian H, Chen J, Katona TR. The influence of PDL principal fibers in a 3-dimensional analysis of orthodontic tooth movement. Am J Orthod Dentofac Orthop. 2001;120(3):272-9.

173. Wu J, Liu Y, Peng W, Dong H, Zhang J. A biomechanical case study on the optimal orthodontic force on the maxillary canine tooth based on finite element analysis. J Zhejiang Univ B. 2018;19(7):535-46.

174. Sharanraj V, Ramesha CM, Kumar V, Sadashiva M. Finite Element Analysis of Zirconia Ceramic Biomaterials Used in Medical Dental Implants. Interceram-International Ceram Rev. 2019;68(3):24-31.

175. de Melo Jr EJM, Francischone CE. Three-dimensional finite element analysis of two angled narrow-diameter implant designs for an all-on-4 prosthesis. J Prosthet Dent. 2020;124(4):477-84.

176. Elsayyad AA, Abbas NA, AbdelNabi NM, Osman RB. Biomechanics of 3-implant-supported and 4-implantsupported mandibular screw-retained prostheses: A 3D finite element analysis study. J Prosthet Dent. 2020;

177. Tsouknidas A, Karaoglani E, Michailidis N, Kugiumtzis D, Pissiotis A, Michalakis K. Influence of preparation depth and design on stress distribution in maxillary central incisors restored with ceramic veneers: A 3D finite element analysis. J Prosthodont. 2020;29(2):151-60. 


\section{Figure Captions}

Figure 1. FEA application procedure.

Figure 2. The systematic flow chart of the study selection process.

Figure 3. A sample tooth model (mandibular left central incisor) and its component cross section

\section{$\underline{\text { Table Captions }}$}

Table 1. The data of the material properties of tooth components extracted from the studies included

Table 2. The maximum, minimum and mean value of the mechanical properties of teeth. 


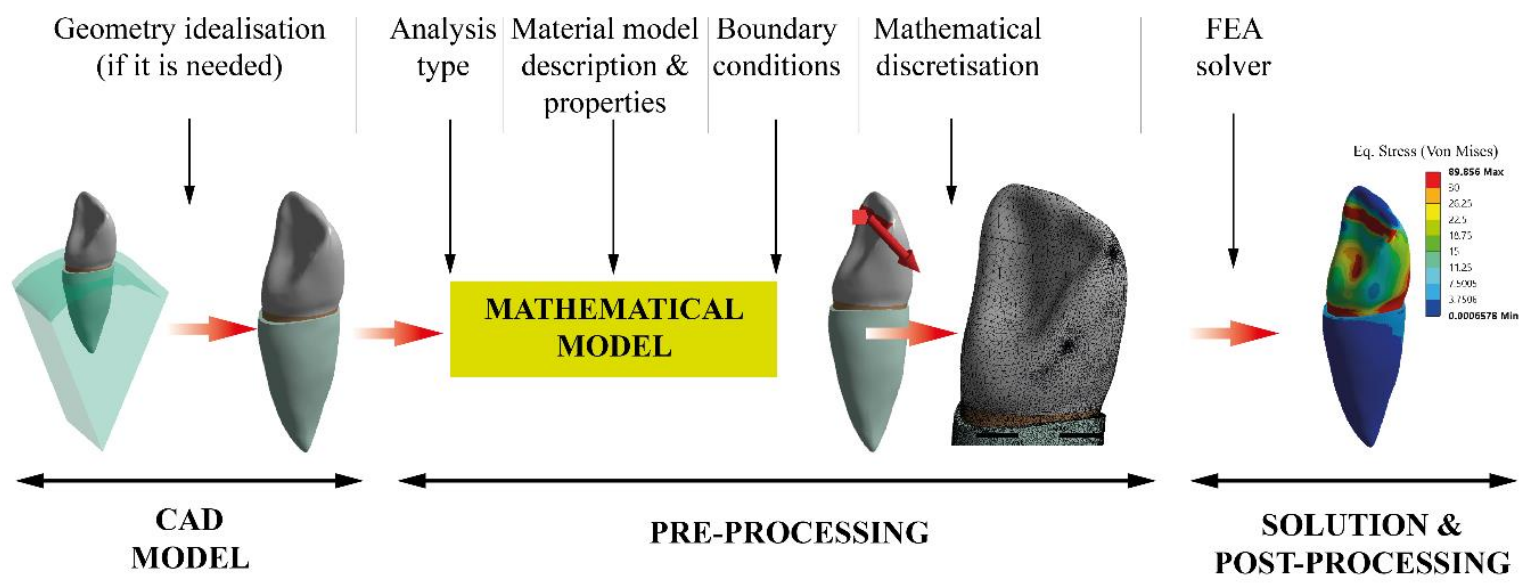

Figure 1. FEA application procedure. 


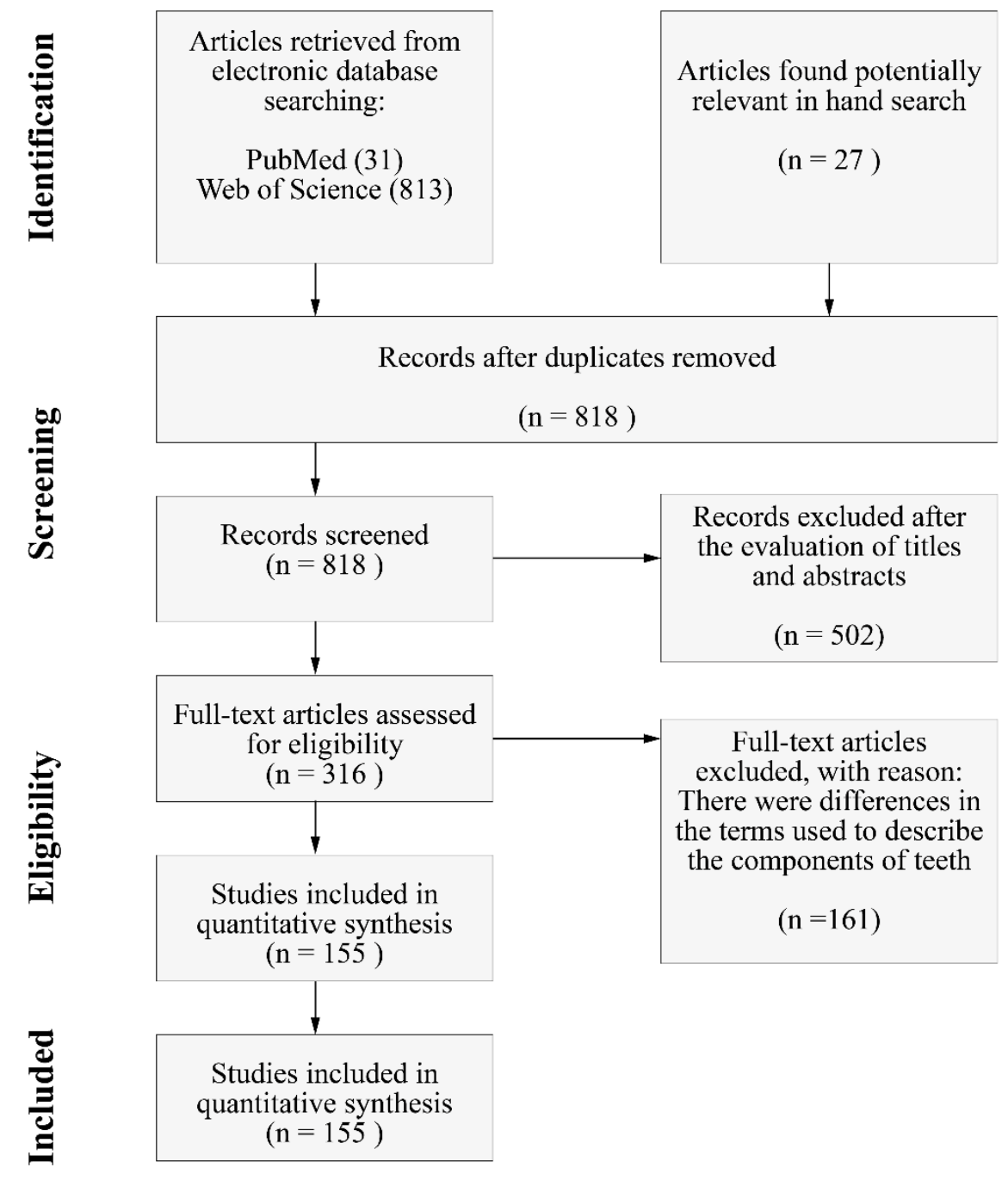

Figure 2. The systematic flow chart of the study selection process 
Sample Tooth Cross Section

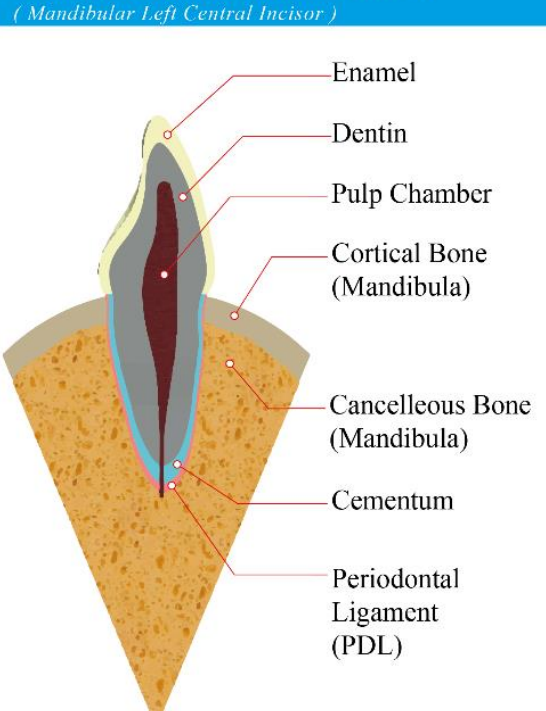

Figure 3. A sample tooth model (mandibular left central incisor) and its component cross section 
Table 1. The data of the material properties of tooth components extracted from the studies included

\begin{tabular}{|c|c|c|c|c|c|c|c|}
\hline Material & & Elastic Module & Poisson's Ratio & & Density & Tensile Strength & Compressive Strength \\
\hline Enamel & $\begin{array}{l}41.0 \\
41.4 \\
46.8 \\
48.0 \\
50.0 \\
60.0 \\
72.7 \\
75-10 \\
77.9 \\
80.0 \\
82.0 \\
82.5 \\
83.0 \\
84.0 \\
84.1 \\
85.0\end{array}$ & $\begin{array}{l}\text { GPa }(25-35), \\
\text { GPa }(36,37), \\
\text { GPa }(38), \\
\text { GPa }(39), \\
\text { GPa }(40), \\
\text { GPa }(41), \\
\text { GPa }(42-44) \\
\mathbf{~ G P a ~}(45), \\
\text { GPa }(46-48), \\
\mathbf{G P a}(49-56), \\
\mathbf{G P a}(41), \\
\mathbf{G P a}(57), \\
\mathbf{G P a}(58) \\
\mathbf{G P a}(59-64), \\
\mathbf{G P a}(5,46,61,65-106), \\
\mathbf{G P a}(107),\end{array}$ & $\begin{array}{ll}\mathbf{0 . 0 0 2} & (77) \\
\mathbf{0 . 2} & (75,76,78,85,86,96,97,102), \\
\mathbf{0 . 2 3 - 0 . 3 0}(108), \\
\mathbf{0 . 3 0} & (25-27,29,30,32,34-38,40,49- \\
& 51,53,56,61,62,73,74,79,87,88,93,95,98,99 \\
& , 103,109,110), \\
\mathbf{0 . 3 1} & (28,52,89,111,112), \\
\mathbf{0 . 3 3} & (5,33,39,42-44,46,48,54,55,57-60,63- \\
& 68,70-72,80-84,90-92,94,100,101,104- \\
& 107,113,114), \\
\mathbf{0 . 4} & (45),\end{array}$ & $\begin{array}{l}2.1 \\
2.5 \\
2.8 \\
3 \\
4\end{array}$ & $\begin{array}{l}\mathbf{g ~ c m}^{-3}(110), \\
\mathbf{g ~ c m}^{-3}(18), \\
\mathbf{g ~ c m}^{-3}(81,84,103) \\
\mathbf{g ~ c m}^{-3}(46,48) \\
\mathbf{g ~ c m}^{-3}(29)\end{array}$ & $\begin{array}{ll}\mathbf{1 0} & \text { MPa }(37) \\
10.3 & \text { MPa }(50,74,103), \\
11.5 & \text { MPa }(90,105), \\
\text { 30-35 } & \text { MPa }(51)(108), \\
\text { 48 } & \text { MPa }(39),\end{array}$ & $\begin{array}{ll}\text { 95-386 } & \text { MPa }(51,108), \\
384 & \text { MPa }(50,74,90,103,105), \\
\text { 288-400 } & \text { MPa }(37)\end{array}$ \\
\hline Dentin & \begin{tabular}{l|}
$10.2-$ \\
11.7 \\
12 \\
13 \\
13.8 \\
14.7 \\
15 \\
16 \\
16.6 \\
16.7 \\
18 \\
\\
18.3 \\
18.5 \\
18.6 \\
\\
\\
19 \\
20 \\
20.7 \\
21
\end{tabular} & $\begin{array}{l}.6 \mathbf{G P a}(108), \\
\text { GPa }(109), \\
\text { GPa }(40), \\
\text { GPa }(39), \\
\text { GPa }(36), \\
\text { GPa }(115,116), \\
\text { GPa }(52), \\
\text { GPa }(46), \\
\text { GPa }(47,48), \\
\text { GPa }(117), \\
\text { GPa }(5,26,55,59,63,113,118- \\
122), \\
\text { GPa }(65,94,103), \\
\text { GPa }(93), \\
\text { GPa }(25,29-35,37,38,42- \\
44,49,51,54,56-58,60-62,66- \\
68,71-88,90-92,96-98,100- \\
102,104-106,111,112,122-152), \\
\text { GPa }(27,41,153), \\
\text { GPa(50,64,95,99,154) } \\
\text { GPa }(155), \\
\text { GPa }(107),\end{array}$ & $\begin{array}{ll}\mathbf{- 0 . 1 1 - 0 . 0 7}(108), \\
\mathbf{0 . 3 0} & (29,36,42,73,109,110,127,153-156), \\
\mathbf{0 . 3 1} & (5,25-27,30-35,38,39,43,44,46,48- \\
& 52,54-68,71,74-78,80,81,83-88,90- \\
& 100,102-107,111- \\
& 113,115,116,118,119,121-123,125- \\
& 129,131,132,134-136,138-152,157,158) \\
\mathbf{0 . 3 2} & (37,72,79,82,101,104,130,137), \\
\mathbf{0 . 3 3} & (120)\end{array}$ & $\begin{array}{l}2 \\
2.20 \\
2.9 \\
2.97\end{array}$ & $\begin{array}{ll}\mathbf{g ~ c m}^{-3} & (81,84,103), \\
\mathbf{g ~ c m}^{-3} & (46-48), \\
\mathbf{g ~ c m}^{-3} & (108), \\
\mathbf{g ~ c m}^{-3} & (110)\end{array}$ & $\begin{array}{ll}\mathbf{1 0} & \mathbf{M P a}(39), \\
\mathbf{4 0 - 2 7 6} & \mathbf{M P a}(51,108), \\
\mathbf{4 8} & \mathrm{MPa}(37) \\
\mathbf{5 1 . 7} & \mathrm{MPa}(103), \\
\mathbf{9 8 . 7} & \mathbf{M P a}(50,74,124), \\
\mathbf{1 0 5 . 5} & \mathbf{M P a}(90,105), \\
\mathbf{2 3 4} & \mathbf{M P a}(117),\end{array}$ & $\begin{array}{ll}\mathbf{2 3 2 - 2 9 7} & \text { MPa }(37) \\
\mathbf{2 4 9 - 3 1 5} & \mathrm{MPa}(51,108), \\
\mathbf{2 8 8} & \mathrm{MPa}(39), \\
\mathbf{2 9 7} & \mathrm{MPa}(50,74,90,103,105,124),\end{array}$ \\
\hline
\end{tabular}




\begin{tabular}{|c|c|c|c|c|c|c|c|c|}
\hline $\begin{array}{l}\text { Periodontal } \\
\text { Ligament (PDL) }\end{array}$ & $\begin{array}{l}\text { 0.01-100 } \\
0.15 \\
0.5 \\
0.75-1.5 \\
11.76 \\
12 \\
20 \\
50 \\
\\
50-100 \\
66.7 \\
68 \\
68.9 \\
\\
\\
69 \\
70 \\
170 \\
175\end{array}$ & $\begin{array}{l}\mathbf{M P a}(159), \\
\text { MPa }(160), \\
\text { MPa }(133), \\
\text { MPa }(96), \\
\text { MPa }(116), \\
\text { MPa }(75,76), \\
\text { MPa }(154,161), \\
\text { MPa }(32,33,36,46- \\
48,74,85,95,99,110,122,124,14 \\
0) \\
\text { MPa }(65), \\
\text { MPa }(162), \\
\text { MPa }(86,87), \\
\text { MPa } \\
\text { (2,25,28,30,34,35,42,49,51,54, } \\
60,66,68,71,77,82,88,91,92,94, \\
106,111,112,114,115,119,121, \\
123,125- \\
128,131,132,136,141- \\
143,145- \\
147,151,155,157,163-166), \\
\text { MPa } \\
\text { (59,84,104,113,118,120,138,13 } \\
\text { 9,144,152), } \\
\text { MPa }(78,97), \\
\text { MPa }(153), \\
\text { MPa }(107),\end{array}$ & $\begin{array}{l}0.30 \\
0.45 \\
\\
\\
\\
\\
0.46 \\
0.49\end{array}$ & $\begin{array}{l}(36,154,161,167), \\
(2,5,25,28,30,34,35,42,46,48,49,51,54,59 \\
, 60,65,66,68,71,74- \\
78,82,85,87,88,91,92,94,96,97,104,106,1 \\
07,110,111,113,115,118-128,131- \\
133,136,138-143,145-147,151- \\
153,155,157,159,160,163,165,166,168), \\
(114), \\
(32,33,86,95,99,116,162,164)\end{array}$ & $\begin{array}{l}0.95 \\
1.10\end{array}$ & $\begin{array}{l}\mathbf{g ~ c m}^{-3}(110) \\
\mathbf{g ~ c m}^{-3}(46-48)\end{array}$ & $\mathbf{X}$ & $\mathbf{X}$ \\
\hline Pulp Chamber & $\begin{array}{l}3 \times 10^{-3} \\
2 \\
2.03 \\
2.07 \\
2.1 \\
3.0 \\
6.89 \\
20\end{array}$ & $\begin{array}{l}\text { MPa }(36,37), \\
\text { MPa } \\
(5,25,30,35,44,56,61,62,76,77, \\
81,86,88,93,96,97,102,119), \\
\text { MPa }(65,67), \\
\text { MPa } \\
(27,33,50,55,64,92,94,106), \\
\text { MPa }(49,51,54), \\
\text { MPa }(28,31,32,38,111,120), \\
\text { MPa }(46-48,68,87), \\
\text { MPa }(153),\end{array}$ & 0.45 & $\begin{array}{l}(5,25,28,30-33,35-38,44,46,48-51,54- \\
56,61,62,64,65,67,68,76,77,81,84,86- \\
88,92- \\
94,96,97,102,106,111,112,119,120,144,1 \\
53),\end{array}$ & $\begin{array}{l}1 \\
1.1\end{array}$ & $\begin{array}{l}\mathbf{g ~ c m}^{-3}(46-48), \\
\mathbf{g ~ c m}^{-3}(84)\end{array}$ & $\mathbf{X}$ & $\mathbf{X}$ \\
\hline Cementum & \begin{tabular}{l|}
2.7 \\
3.58 \\
6 \\
7 \\
7.18 \\
8.2 \\
15 \\
18 \\
18.6 \\
22.4
\end{tabular} & $\begin{array}{l}\text { GPa }(26), \\
\text { GPa }(169), \\
\text { GPa }(91), \\
\text { GPa }(134), \\
\text { GPa }(114), \\
\text { GPa }(170), \\
\text { GPa }(67), \\
\text { GPa }(59,113), \\
\text { GPa }(128,136), \\
\text { GPa }(129),\end{array}$ & \begin{tabular}{l|l|l|l|l}
.27 \\
0.30 \\
0.31 \\
0.322 \\
0.35
\end{tabular} & $\begin{array}{l}(91) \\
(26,134,170), \\
(59,67,113,128,136), \\
(114), \\
(129),\end{array}$ & 2.03 & $\mathrm{~g} \mathrm{~cm}^{-3}(171)$ & $29 \quad$ MPa (129), & 32.1 MPa (169), \\
\hline
\end{tabular}




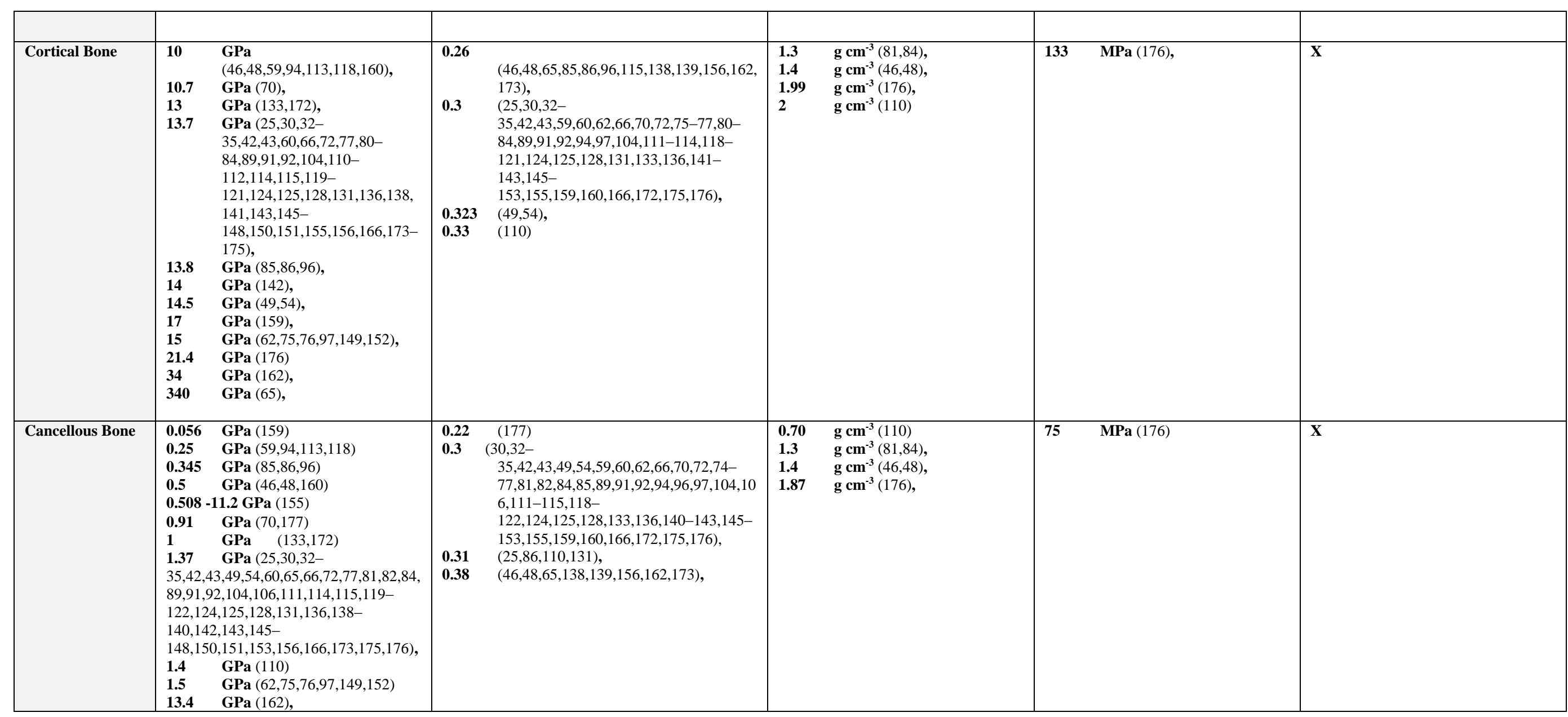


Table 2. The maximum, minimum and mean value of the mechanical properties of teeth.

\begin{tabular}{|c|c|c|c|c|c|}
\hline Material* & Elastic Modulus & $\begin{array}{c}\text { Poisson's Ratio } \\
(-)\end{array}$ & $\begin{array}{l}\text { Density } \\
\left(\mathrm{g} \mathrm{cm}^{-3}\right)\end{array}$ & $\begin{array}{c}\text { Tensile Strength } \\
\text { (MPa) }\end{array}$ & $\begin{array}{c}\text { Compressive } \\
\text { Strength } \\
\text { (MPa) }\end{array}$ \\
\hline Enamel & $\begin{array}{l}\text { Min }: 40 \mathrm{GPa} \\
\text { Max }: 100 \mathrm{GPa} \\
\text { Average }: 70 \mathrm{GPa}\end{array}$ & $\begin{array}{ll}\text { Min } & : 0.002 \\
\text { Max } & : 0.4 \\
\text { Average } & : 0.2\end{array}$ & $\begin{array}{ll}\text { Min } & : 2.5 \\
\text { Max } & : 4 \\
\text { Average } & : 2.8\end{array}$ & $\begin{array}{ll}\text { Min } & : 10 \\
\text { Max } & : 48 \\
\text { Average } & : 24\end{array}$ & $\begin{array}{ll}\text { Min } & : 95 \\
\text { Max } & : 400 \\
\text { Average } & : 310\end{array}$ \\
\hline Dentin & $\begin{array}{l}\text { Min }: 12 \mathrm{GPa} \\
\text { Max }: 21 \mathrm{GPa} \\
\text { Average }: 17 \mathrm{GPa}\end{array}$ & $\begin{array}{ll}\text { Min } & : 0 \\
\text { Max } & : 0.3 \\
\text { Average } & : 0,2\end{array}$ & $\begin{array}{l}\text { Min:2 } \\
\text { Max:2.9 } \\
\text { Average:2.5 }\end{array}$ & $\begin{array}{ll}\text { Min } & : 10 \\
\text { Max } & : 276 \\
\text { Average } & : 108\end{array}$ & $\begin{array}{lr}\text { Min } & : 232 \\
\text { Max } & : 315 \\
\text { Average }: 279\end{array}$ \\
\hline $\begin{array}{l}\text { Periodontal } \\
\text { Ligament (PDL) }\end{array}$ & $\begin{array}{ll}\text { Min } & : 0.5 \mathrm{MPa} \\
\text { Max } & : 175 \mathrm{MPa} \\
\text { Average } & : 50.8 \mathrm{MPa}\end{array}$ & $\begin{array}{ll}\text { Min } & : 0.3 \\
\text { Max } & : 0.5 \\
\text { Average } & : 0.4\end{array}$ & $\begin{array}{l}\text { Min : } 1.1 \\
\text { Max : }- \\
\text { Average : - }\end{array}$ & - & - \\
\hline Pulp Chamber & $\begin{array}{ll}\text { Min } & : 0.003 \mathrm{MPa} \\
\text { Max } & : 7 \mathrm{MPa} \\
\text { Average } & : 4.75 \mathrm{MPa}\end{array}$ & $\begin{array}{l}\text { Min }: 0.45 \\
\text { Max : - } \\
\text { Average : - }\end{array}$ & $\begin{array}{lr}\text { Min } & : 1 \\
\text { Max } & : 1 \\
\text { Average } & : 1\end{array}$ & - & - \\
\hline Cementum & $\begin{array}{ll}\text { Min } & : 2.7 \mathrm{GPa} \\
\text { Max } & : 22.4 \mathrm{GPa} \\
\text { Average } & : 10.6 \mathrm{GPa}\end{array}$ & $\begin{array}{ll}\text { Min } & : 0.2 \\
\text { Max } & : 0.3 \\
\text { Average }: & 0.2\end{array}$ & $\begin{array}{l}\text { Min }: 2.03 \\
\text { Max : - } \\
\text { Average : - }\end{array}$ & $\begin{array}{l}\text { Min :29 } \\
\text { Max :- } \\
\text { Average : - }\end{array}$ & $\begin{array}{l}\text { Min :32 } \\
\text { Max :- } \\
\text { Average : - }\end{array}$ \\
\hline Cortical Bone & $\begin{array}{ll}\text { Min } & : 10 \mathrm{GPa} \\
\text { Max } & : 34 \mathrm{GPa} \\
\text { Average } & : 16 \mathrm{GPa}\end{array}$ & $\begin{array}{lc}\text { Min } & : 0.2 \\
\text { Max } & : 0.3 \\
\text { Average } & : 0.3\end{array}$ & $\begin{array}{ll}\text { Min } & : 1.3 \\
\text { Max } & : 2 \\
\text { Average } & : 1.6\end{array}$ & $\begin{array}{l}\text { Min :133 } \\
\text { Max : - } \\
\text { Average : - }\end{array}$ & - \\
\hline Cancellous Bone & $\begin{array}{ll}\text { Min } & : 0.05 \mathrm{GPa} \\
\text { Max } & : 13.4 \mathrm{GPa} \\
\text { Average } & : 2.65 \mathrm{GPa}\end{array}$ & $\begin{array}{ll}\text { Min } & : 0.2 \\
\text { Max } & : 0.3 \\
\text { Average } & 0.3\end{array}$ & $\begin{array}{lr}\text { Min } & : 0.7 \\
\text { Max } & : 1.8 \\
\text { Average } & : 1.3\end{array}$ & $\begin{array}{l}\text { Min }: 75 \\
\text { Max : } \\
\text { Average : - }\end{array}$ & - \\
\hline
\end{tabular}

